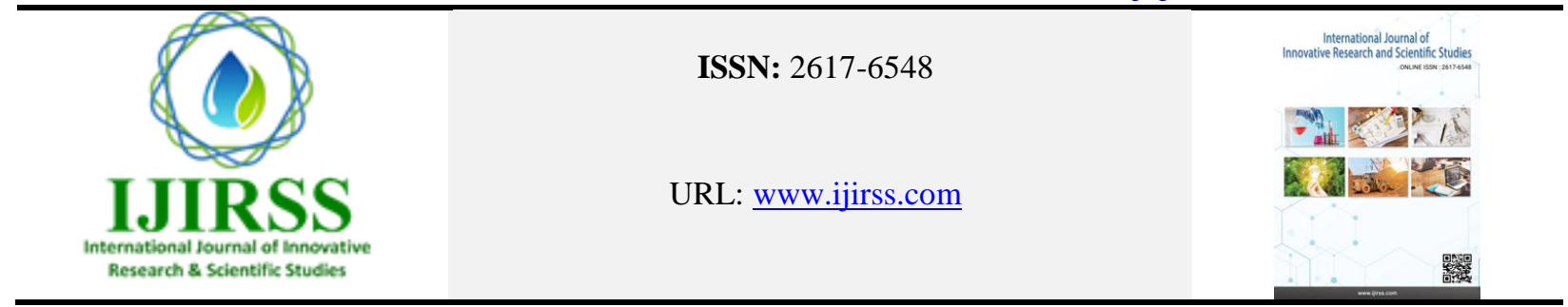

\title{
The Mediation Effect of Job Satisfaction between Reward System and Training and Development on Employee Retention in Yemen's Banking Sector
}

\author{
Hareth Abd Al-Wareth Alrazehi1 ${ }^{*}$, (D) Noor Aina Amirah², (D) Ali Salman Mohammed Emam ${ }^{3}$
}

\author{
${ }^{1,2}$ Faculty of Business and Management, Universiti Sultan Zainal Abidin, Malaysia. \\ ${ }^{3}$ Department of Management, College of Business Administration, University of Hafr Al-Batin, Saudi Arabia Department of Business \\ Administration, College of Commerce \& Economics, Hodeidah University, Yemen.
}

*Corresponding author: Hareth Abd Al-Wareth Alrazehi (razhyhareth@gmail.com)

\begin{abstract}
This study was conducted to determine the effect of rewards systems and training and development on employee retention, mediated by the effects of job satisfaction, in Yemeni commercial banks. The study used cross-sectional data collection methods. Data was collected from the headquarters of 15 commercial banks. A set of questionnaires using a 5-point Likert scale was distributed to employees; the data was analyzed using the Structured Equation Model (SEM) by IBM SPSS AMOS 25.0. The results indicated that both the rewards system and training and development significantly affect job satisfaction, while job satisfaction has a significant positive effect on employee retention. Training and development themselves have no statistically significant effect on employee retention. The results showed that job satisfaction plays a mediating role because the indirect effect is significant. The mediation is complete because the direct impact is not significant. The result indicates that job satisfaction is an important variable that links the reward system and training and development to employee retention in Yemeni banks. This study is expected to make significant theoretical, practical, and methodological contributions to this field of research due to the development of a model of the effects of the reward system and training and development on employee retention through job satisfaction.
\end{abstract}

Keywords: Banking sector of Yemen, Employee retention, Job satisfaction, Reward system, Training and development.

DOI: $10.53894 /$ ijirss.v4i4.100

Funding: This study received no specific financial support.

History: Received: 23 June 2021/Revised: 26 July 2021/Accepted: 30 August 2021/Published: 21 September 2021

Licensed: This work is licensed under a Creative Commons Attribution 4.0 License $($ (c) Er

Acknowledgement: The authors express their sincere gratitude to all participants for responding the questions and to the educational institutions for allowing them in questionnaire distribution and data collection.

Competing Interests: The authors declare that they have no conflict of interests.

Transparency: The authors confirm that the manuscript is an honest, accurate, and transparent account of the study was reported; that no vital features of the study have been omitted; and that any discrepancies from the study as planned have been explained.

Ethical: This study follows all ethical practices during writing.

\section{Introduction}

The banking sector in Yemen is vital to the national economy due to its significant contributions to economic activities. However, Yemeni banks struggle to compete in the international arena [1]. The literature has revealed that the ineffective management of interpersonal and technical skills has adversely affected employees' working performance in Yemeni banks [2]. Another study has reported that Yemeni bank management teams have failed to adequately cope with their employees' needs due to poor communication, leading to issues of poor employee satisfaction and ultimately high turnover rates [3]. 
Rageh, et al. [4] have noted that the Central Bank of Yemen opted to relocate 800 employees from Sana'a to Aden. The relocation resulted in a high turnover rate among their employees. Moreover, between January and May 2016, a the banking system's budget was reduced by 160 Billion YER, causing Yemeni banks such as the International Bank of Yemen and Arab Bank Limited to be worse off [4]. According to Shawtari, et al. [5], the Yemeni banking industry is facing instability and a decline in efficiency, and one reason for this could be employee turnover. High turnover rates may be caused by a lack of functional satisfaction, which is generally triggered by limitations in the reward system, as well as training and development.

The problem faced by the Yemeni banking sector is similar to that faced by the banking sectors in other Third World countries. The challenge of retaining employees has stumped many managers and business owners. The constant turnover of employees has implications for the remaining employees, as the remaining staff must cope with an increased workload [6]. Failure to retain crucial employees has given rise to specific issues in the financial sector, including increased training time and lost knowledge. The costs of employee turnover are high and can seriously impact an organization's bottom line $[7,8]$.

Thus, the problem of employee satisfaction and eventual retention is the main focus of this paper. These issues are related to customer satisfaction and have an impact on banking operations overall. Employees represent the main link between customers and the bank. A lack of job satisfaction negatively affects their productivity and effectiveness, which in turn negatively affects their dealings with clients. Accordingly, the current research aims to bridge the gap in the literature by assessing the current situation of the banking sector in Yemen. Also, insight into the effects of training and job satisfaction on the retention of employees in Yemen's banking sector should improve the current condition of banks in Yemen. The practical evaluation presented in this study provides an in-depth understanding of the interconnected relationships between employee training, employee satisfaction, employee retention, and ultimately the improvement of the commercial operations of the Yemeni banking sector.

\section{Understanding the Concept of Employee Retention}

Employee retention can be defined as the policies or practices employed by a particular company or organization to prevent the workforce from leaving their jobs. Organizations have to make an effort on several different levels to encourage employees to dedicate themselves and identify with the company [9]. Keeping an employee in an organization depends on the employee's commitment to the company $[10,11]$.

Retaining valuable employees is an effective way to avoid financial consequences [12]. In a business environment that has become increasingly sophisticated and contemporary, organizations need to retain these highly skilled and distinguished employees because they can contribute to the organization's sustainability [13]. According to Mehta, et al. [10], several factors influence an employee's commitment towards a job or an organization. These factors include organizational culture, compensations, strategy, and work-life policy.

One of the most critical issues that organizations must pay attention to is that a high level of staff turnover will have implications for the rest of the staff, as they will be subject to an increased workload [6].

\subsection{Reward System}

The main purpose of a reward system is to attract, retain and motivate employees by increasing their job satisfaction. Previous studies have revealed that organizations can increase employees' job satisfaction through a fair reward system [14, 15]. Reward systems can be divided into two categories, monetary rewards and non-monetary rewards. Monetary rewards refer to increased remuneration, cash incentives, and financial support, whereas non-monetary rewards include an enhanced work-life balance, support from supervisors, and employee recognition [16]. In addition, Kalén [17] mentioned that there is a positive relationship between employee performance and their wages in an organization.

A person's identity is their perception of who they are and what they want to be. This is one of the most important factors that affects their economic life and may indicate the most appropriate incentives for them to perform their job. Lazear [18] showed that most employees carry out their duties with increased diligence and concern when employers increase their salaries. Fisseha-Zemene [19] mentioned that employee benefits such as health insurance, vacation pay, or retirement pension are important indirect financial rewards. The benefits provided by an employer are not only a mechanism to improve employees' performance, but also help to attract applicants to the recruitment process.

\subsection{Training and Development}

Training and development refer to the process and method involved in improving the aptitude, skills, knowledge, ability, and attitude of employees to perform their specific work-related job [20,21]. Training encourages employees to upgrade their previous skills and knowledge and become acquainted with the latest innovations. Armstrong and Taylor [22] defined training and development as the systematic increase of knowledge, skills, and abilities that enables an employee to perform their job-related duties in the organization. It has been reported that organizational training programs can improve employees' skills [23]. Therefore, it can be argued that on-the-job training and educational programs are critical in improving the efficiency and performance of employees. Besides that, they also increase employees' job satisfaction [24].

According to Chaudhry, et al. [25], training and development are crucial to enhance employees' performance. Training and development improve individual and organization superiority and improve the practical skills of employees. Training is concerned with two main areas; the first is organizational efficiency, and the second is related to people and technology. 


\subsection{Job Satisfaction}

According to Alrazehi, et al. [26], job satisfaction can be defined as an employee's positive feelings about a job, based on their evaluation and their perceptions of the job's features. The concept of job satisfaction is believed to be both multifaceted and challenging for a company to achieve.

Job satisfaction is, however, critical for optimum performance; it encourages and motivates the employee towards achieving strategic goals at the workplace. According to a study conducted by Mehrad, et al. [27], job satisfaction is a basic human need, and it impacts on the employee's performance. Raziq and Maulabakhsh [28] further added that employees' satisfaction is critical to the success of an organization.

The job satisfaction of employees is directly associated with their working environment. It consists of two major dimensions: the work and the context within which the work is carried out. The dimension of work covers all the operational activities, such as task completion, control over task-related activities, intrinsic motivation to complete tasks, the value of tasks, and the variety of tasks. Studies have explored the role of intrinsic motivation in completing tasks and revealed that intrinsic motivation is significantly associated with an employee's job satisfaction. The second broad dimension of work is the context in which employees work. This includes the working conditions and the social interactions with fellow employees [29, 30].

\subsection{The Effect of Reward Systems on Job Satisfaction}

The term job satisfaction has received much attention. Experts have tried to identify different constituents of job satisfaction, evaluate their relative importance, and analyze the impact of each on workers' productivity [31]. Riketta, et al. [32] also suggested that employees' workplace behavior is associated with job satisfaction. Bayliss, et al. [33] practical research also demonstrated that the management's efforts to create promotion opportunities contribute to employees' job satisfaction and act as a catalyst for job performance. Furthermore, experts have noted that rewards firms offer might strongly affect the staff's behavior relating to the job and the organization they work for [34].

According to Tietjen and Myers [35], in Two-factor Theory, rewards can offered in both intrinsic and extrinsic forms, which can positively affect an employee's working experience [31]. Also, studies have revealed that when an intrinsic reward is considered the epitome of job satisfaction [36], the satisfaction of the extrinsic reward will result in ongoing commitment to the firm and subsequently lead to increased customer satisfaction and loyalty. In this regard, it is worth noting the study results of Priya and Eshwar [31], who researched government and private commercial banks in Chennai. Their results confirmed a significant relationship between bonuses and job satisfaction among commercial bank employees in the public and private sectors in Chennai. Thus, the current study examines the effect of a reward system on job satisfaction in Yemen's banking sector by proposing the following hypothesis:

H1: There is a significant relationship between Reward System and employees'Job Satisfaction in Yemen's Banking sector

\subsection{The Effect of Training \& Development on Job Satisfaction}

The training and development of employees in an organization is an important process to upgrade skills and knowledge. In organizations, training and development are associated with increased employee performance [37]. Training and development activities are planned appropriately to cater to the needs of employees. Studies have demonstrated a positive association between training and development and job satisfaction as well as increased productivity. According to Sharma [38], training and development programs enhance job satisfaction and help decrease turnover plans and hiring charges. A recently conducted study found that job training influences employees' satisfaction, which ultimately affects their performance and determines turnover intentions, by helping employees to gain job-related competencies [39].

In another study, Jehanzeb and Mohanty [40] argued that employee development initiatives such as training and development programs significantly impact employee job satisfaction and organizational commitment. Likewise, identified a positive relationship between training and development programs and employee performance and job satisfaction. The study shows that training and development programs are strategic tools an organization can employ to improve employees' job satisfaction. Rahayu, et al. [41] concluded that training development has a positive and significant relationship with job satisfaction. Furthermore, Paposa and Kumar [42] also reported similar results, as they found a high degree of correlation between training and development and job satisfaction. Thus, the current study examines the relationship between training and development and job satisfaction in the Yemeni banking sector by proposing the following hypothesis:

H2: There is a significant relationship between Training and Development and employee Job Satisfaction in Yemen's Banking sector

\subsection{The Effect of Job Satisfaction on Employee Retention}

The contemporary banking environment is rapidly changing, which requires a highly competent workforce. Therefore, to improve the competence of employees, it is imperative to enhance their job satisfaction, which ultimately results in a high rate of retention. Several strategies could help to encourage employees and improve their job satisfaction. However, the banking sector is complex compared to other industries and thus requires a robust strategy for motivating employees. In the banking sector, monetary compensation is not regarded as the best motivator for employees. Although one study reported that monetary reward is critical [43] employees in the banking sector are more interested in the work environment, cooperative supervisors, and regular opportunities to learn new skills and progress in their career [44]. Therefore, it is cardinal for the banking sector to improve employees' job satisfaction to retain their skilled workforce.

One recently conducted study in the health sector revealed that job satisfaction significantly impacts employee turnover [45]. Another study Belete [46] found that employee satisfaction influences employee turnover. It argued that the 
organizations that pay substantial remunerations to employees were more likely to retain them. Similarly, another study reported that person-oriented leadership behavior is critical in improving employee job satisfaction; under such leadership, employees stay committed to the organization and have a minimum incentive for turnover [47]. Thus, the current study examines the effect of job satisfaction on employee retention in Yemen's banking sector by proposing the following hypothesis:

H3: There is a significant relationship between employee Job Satisfaction and Employee Retention in Yemen's Banking sector

\subsection{The Effect of Reward Systems on Employee Retention}

When examining the relationship between working environment, rewards, and employee retention it is important to accurately define the term rewards. Rewards can refer to cash and non-cash rewards, direct and indirect rewards, and the large and external rewards offered to employees that serve as a catalyst and encouragement for them to stay in the organization [48]. According to the statistics issued by the Corporate Leadership Advisory Council, rewards account for $25 \%$ of the decision to stay with an organization [49]. This raises the question whether higher compensation would further motivate talented employees to remain in the organization.

Considering the significant changes and challenges they are faced with, organizations endeavor to improve employee productivity and increase the organization's competitiveness. To do so, they must face the challenges of managing changes to organizational structures and offering rewards so that they are more attractive and contribute to employee retention [50]. In this regard, the results of the study conducted by De Gieter and Hofmans [51] showed that rewards in the form of benefits affect the largest number of employees, causing them to be satisfied and affecting their intentions to leave the organization. It is also worth noting here the results of the study conducted by Akhtar, et al. [52], which indicate that there is a strong and significant relationship between rewards and employee retention. The current study thus examines the relationship between reward system and employee retention in Yemen's banking sector by proposing the following hypothesis:

H4: There is a significant relationship between Reward System and Employee Retention in Yemen's Banking sector

\subsection{The Effect of Training \& Development on Employee Retention}

Training and development help employees to develop a personal competitive advantage and improved performance, which is reflected and positively affects the company's overall performance [53-56]. Employee training is a crucial part of any strategy to motivate and retain employees. Indeed, well-trained employees may achieve many goals by expanding their experience and knowledge. In the service of organizations, motivated employees perform better, which leads them towards personal growth and productivity, and prosperity for the company [57].

Another benefit of training and development is its positive correlation with employee retention. Because this practice meets the needs of employees, they are therefore more motivated to stay in the organization. Looking at the relationship between employee retention, training, and development, Moussa [58] found that training and development are vital for retaining employees. Sinha and Sinha [59] confirmed a positive relationship between training and development and employee retention, concluding that prioritizing the investment strategy of training and developing employees is more effective and an important factor in employee retention. Therefore, the current study examines the effect of training and development on employee retention in Yemen's banking sector by proposing the following hypothesis:

H5: There is a significant relationship between Training and Development and Employee Retention in Yemen's Banking sector

\subsection{The Mediating Effect of Job Satisfaction between Reward System and Employee Retention}

Rewards play an important role in maintaining employee commitment, ensuring a high level of performance. Rewards positively participate in the motivation process, encouraging competition among employees to provide a more effective and distinctive performance [60]. Rewards have important implications for employees' overall work satisfaction and their desire to commit to their work. Dissatisfaction is one of the main reasons employees leave their jobs. In contrast, we find that employees who are satisfied with their jobs will stay longer, and they will be motivated to adapt to various changes and conditions, good or bad, to continue their careers.

A study has shown that high levels of job satisfaction often improve employee retention Manzoor, et al. [61]. Results also indicate that the rewards system is among the factors that may increase their job satisfaction. Therefore, job satisfaction is a crucial factor in retaining employees [62]. Terera and Ngirande [63] discussed the effect of the relationship between rewards and job satisfaction on employee retention. The results show that competitive and profitable reward packages could make employees stay with their organization, and they conclude that the more employees are rewarded or compensated, the more they are inclined to remain in an institution. An important positive relationship was thus discovered between job satisfaction, rewards, and employee retention. Therefore, the current study examines the mediating relationship of job satisfaction between rewards and employee retention in Yemen's banking sector by proposing the following hypothesis:

H6: There is a significant effect of Job Satisfaction as a mediating factor between Reward Systems and Employee Retention in Yemen's Banking sector 


\subsection{The Mediating Effect of Job Satisfaction between Training and Development and Employee Retention}

Employee development helps in career advancement, as well as helping the institution enhance its human resources, which comes through the strengthening of training groups and cognitive skills [64-66]. An employee's age represents his career, activities, and expertise, as well as the areas of training and development that he has benefited from in his career [67]. There is a significant positive relationship between employee development activities and job satisfaction [15, 68, 69]. Nelissen, et al. [70] stressed that job satisfaction is a strong indicator of turnover intention. Therefore, aligning more closely to employee interests will increase job satisfaction and employee retention. Furthermore, El-Bedawy, et al. [71] demonstrated a negative relationship between employee development and employee exhaustion.

Among the studies that discussed the effect of the relationship between training and development and job satisfaction on employee retention is that conducted by Mohamed, et al. [72]. This study was conducted in the banking sector in Sudan. The results revealed that training and development increased employees' commitment to the bank. It confirmed that employees reached a high level of job satisfaction, which would positively reflect on their productivity and efficiency, making them less likely to leave.

Therefore, the current study examines the mediating effect of job satisfaction on the relationship between training and development and employee retention in Yemen's banking sector, by proposing the following hypothesis:

H7: There is a significant effect of Job Satisfaction as a mediating factor between Training and Development and Employee Retention in Yemen's banking sector.

\subsection{Research Framework}

Based on the previous literature, the variables that have been selected for the study are presented in the framework shown in Figure 1, which shows the relationship between employee retention as a dependent variable, reward system and training and development as independent variables, and job satisfaction as a mediating variable. Social Exchange Theory was used to develop the research model. Social Exchange Theory can explain the relationship between rewards and training and development opportunities provided by the organization to the employees and their level of commitment, which is derived from their job satisfaction. Employees work in the social context of an organization in which they interact with each other and the top management. If the managers need high employee performance, they need to motivate them and encourage them towards the organizational goals. Thus, a mutually beneficial association is established between employees and top management. In this way, Social Exchange Theory perfectly conceptualizes the smooth functioning of an organization and, in turn, justifies the selection of this theory as the basis for addressing the issue at hand, namely the effect of reward system and training and development on employee retention and the role of job satisfaction as a mediator of those effects in the Yemeni banking sector.

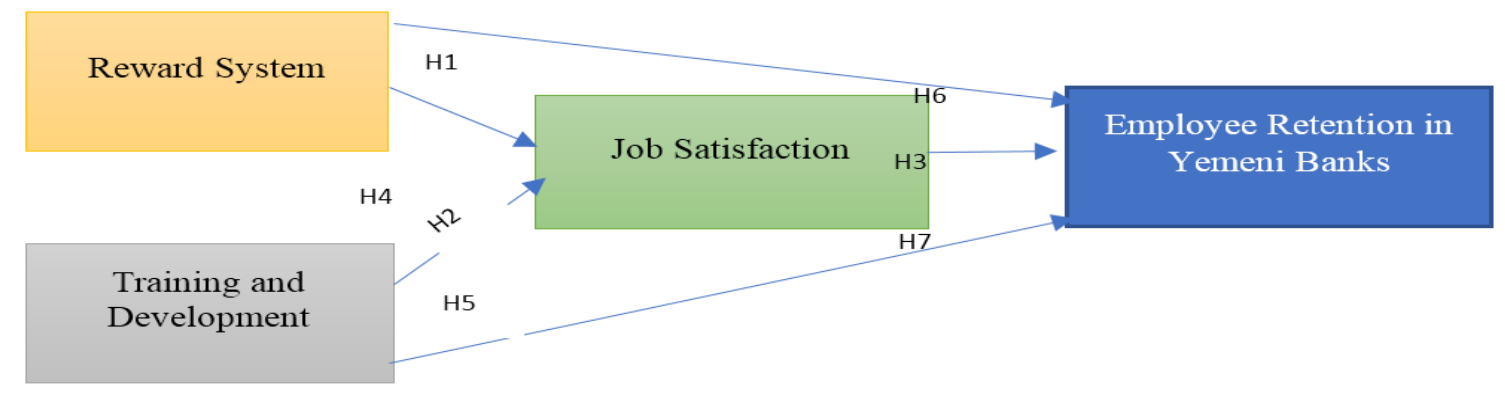

\footnotetext{
Figure-1.

Framework of the study.
}

\section{Methodology}

The current paper aims to test the formulated hypotheses and examine the possible association between the research variables to identify the relationship between job satisfaction as a mediating variable, reward system and training and development as independent variables, and employee retention as the dependent variable, among bank employees in Yemen. Thus, individual bank employees in Yemen represent the unit of analysis for the present study to explain the observed linkages. The research design is a quantitative cross-sectional study involving data collection and analysis. The data collection was mainly done using a questionnaire survey [73]. The findings were analyzed using a correlational design, which helps in investigating the link between two or more variables [74]. Data was collected directly from the employees of Yemeni banks at their headquarters in Sana'a. The questionnaires were administered by the researcher. The population of this study is 2,407 employees among the fifteen banks which represent all commercial banks located in Sana'a. The appropriate sample was chosen through simple random sampling. The justification for selecting this sampling technique was that every element in the population had a known and equal chance of being selected as a subject [75]. Given the nature of the study, all banks in the sample had the same probability of selection. Given a population of just over 2400 employees, a minimum sample size of 331 has been suggested by many scholars to be sufficient for any study [75]. It is difficult to guarantee a $100 \%$ response rate. Therefore, Hair, et al. [76] proposed to increase the number of questionnaires to ensure an adequate response rate to satisfy the minimum sample size. Therefore, 400 sets of questionnaires were distributed. 
Two hundred seventy-two questionnaires were deemed usable, representing a $68 \%$ response rate - in this regard, a response rate of $30 \%$ is considered sufficient for surveys, thus further analysis was carried out [75]. The data collection questionnaire was administered, distributed, and personally collected by the researcher. Data analysis and hypothesis testing were conducted using IBM-SPSS-AMOS 25.0. The questionnaire used a five-point Likert scale ranging from "1" (Strongly Disagree) to "5" (Strongly Agree). The Likert scale is essential for respondents to report their perceptions regarding practices and assessments Al-Marri, et al. [77]. Jun, et al. [78] and Bawan, et al. [79] developed the measurement of Employee Retention as a dependent variable from 7 questionnaire items. The mediating variable of Job Satisfaction was explored through 8 items [80]. Regarding the independent variables, Rewards System was investigated through 8 items [81], while Training and Development consisted of 7 items [82].

\section{Findings of the Study}

\subsection{Assessment of Measurement Model}

This study adopted the two-step approach of Structural Equation Modelling (SEM) as proposed by Awang, et al. [83]. The first step was to construct measurement models through the Confirmatory Factor Analysis (CFA) procedure, while the next step was to measure the structural model. The SEM procedure was employed to estimate the parameters involved and test the hypotheses regarding the inter-relationships among the constructs in the model. Both procedures (CFA and SEM) were carried out using IBM-SPSS-AMOS 25.0. The construct validity was assessed using the list of fitness indexes that the measurement model needs to achieve. According to Aziz, et al. [84] and Awang, et al. [83], there are three categories of model fit that any measurement model needs to achieve for construct validity. The three fitness categories are listed in Table 1 .

Table-1.

The three categories of model fit and their level of acceptance.

\begin{tabular}{l|l|l}
\hline Name of category & Name of index & Level of acceptance \\
\hline \multirow{2}{*}{ Absolute Fit Index } & RMSEA & RMSEA $<0.08$ \\
\cline { 2 - 3 } & GFI & GFI $>0.90$ \\
\hline \multirow{2}{*}{ Incremental Fit Index } & AGFI & AGFI $>0.90$ \\
\cline { 2 - 3 } & CFI & CFI $>0.90$ \\
\cline { 2 - 3 } & TLI & TLI $>0.90$ \\
\cline { 2 - 3 } & NFI & NFI $>0.90$ \\
\hline Parsimonious Fit Index & Chisq/df & Chi-Square/ df $<5.0$ \\
\hline
\end{tabular}

The fitness indexes in Figure 2 met the threshold values, as listed in Table 1. The RMSEA was 0.081 (close to the threshold of less than 0.08), the CFI was 0.946 (achieved the threshold of greater than 0.90), and the ratio of Chisq/df was 3.088 (achieved the threshold of 3.0). Thus, the measurement model of all latent constructs in Figure 2 met the requirements for construct validity $[85,86]$. A convergent validity assessment was conducted to compute the AVE. A construct achieves convergent validity if its AVE exceeds the threshold value of 0.5 [87]; [88]. The CR was computed to assess the composite reliability, and its value should exceed the threshold value of 0.6 to meet the requirements of reliability [89]. The factor loading for all items was obtained and is tabulated in Table 2. The AVE was computed to assess convergent validity. The value to determine the composite reliability was also computed using the factor loading. The Cronbach's alpha values and Composite Reliability should be significantly higher than 0.70 [90]. The internal consistency of the procedures has been verified for reliability, as shown in Table 2.

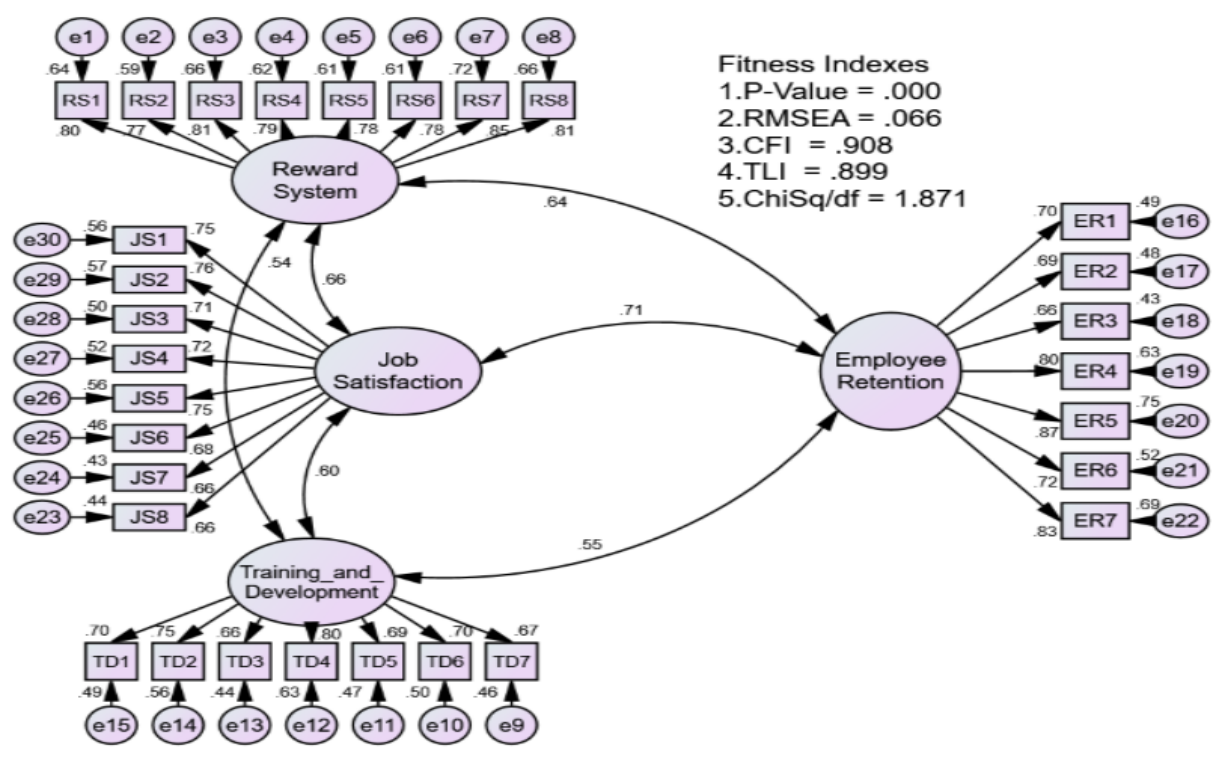

Figure-2.

Assessment of the Research Model. 
Table-2.

Assessment of Measurement Model.

\begin{tabular}{|c|c|c|c|c|c|}
\hline Construct & Item & Factor Loading & $\begin{array}{c}\text { Cronbach's } \\
\text { Alpha }\end{array}$ & $\begin{array}{c}\text { CR } \\
\text { (above 0.6) }\end{array}$ & $\begin{array}{c}\text { AVE } \\
\text { (above 0.5) }\end{array}$ \\
\hline \multirow[t]{8}{*}{ Reward System } & RS1 & 0.80 & \multirow[t]{8}{*}{0.901} & \multirow[t]{8}{*}{0.934} & \multirow[t]{8}{*}{0.639} \\
\hline & $\mathrm{RS} 2$ & 0.77 & & & \\
\hline & RS3 & 0.81 & & & \\
\hline & RS4 & 0.79 & & & \\
\hline & RS5 & 0.78 & & & \\
\hline & RS6 & 0.78 & & & \\
\hline & RS7 & 0.85 & & & \\
\hline & RS8 & 0.81 & & & \\
\hline \multirow[t]{7}{*}{ Training and Development } & TD1 & 0.70 & \multirow[t]{7}{*}{0.801} & \multirow[t]{7}{*}{0.877} & \multirow[t]{7}{*}{0.506} \\
\hline & TD2 & 0.75 & & & \\
\hline & TD3 & 0.66 & & & \\
\hline & TD4 & 0.80 & & & \\
\hline & TD5 & 0.69 & & & \\
\hline & TD6 & 0.70 & & & \\
\hline & TD7 & 0.67 & & & \\
\hline \multirow[t]{8}{*}{ Job Satisfaction } & JS1 & 0.75 & \multirow[t]{8}{*}{0.849} & \multirow[t]{8}{*}{0.891} & \multirow[t]{8}{*}{0.507} \\
\hline & JS2 & 0.76 & & & \\
\hline & JS3 & 0.71 & & & \\
\hline & JS4 & 0.72 & & & \\
\hline & JS5 & 0.75 & & & \\
\hline & JS6 & 0.68 & & & \\
\hline & JS7 & 0.66 & & & \\
\hline & JS8 & 0.66 & & & \\
\hline \multirow[t]{7}{*}{ Employee Retention } & ER1 & 0.70 & \multirow[t]{7}{*}{0.841} & \multirow[t]{7}{*}{0.903} & \multirow[t]{7}{*}{0.572} \\
\hline & ER2 & 0.69 & & & \\
\hline & ER3 & 0.66 & & & \\
\hline & ER4 & 0.80 & & & \\
\hline & ER5 & 0.87 & & & \\
\hline & ER6 & 0.72 & & & \\
\hline & ER7 & 0.83 & & & \\
\hline
\end{tabular}

A discriminant validity assessment was conducted to ensure no redundant constructs occurred in the model. The researchers conducted the discriminant validity test by measuring the Fornell-Larcker criterion by taking the square root of the AVE values. The square root of each latent construct's AVE should be greater than its highest correlation with any other latent construct [91]. Table 3 displays a summary of the discriminant validity index. The diagonal values are the square root of the AVE of the respective constructs, while the other values are the correlation coefficients between the respective pair of constructs [92].

Table-3.

The Discriminant Validity Index Summary for all Constructs.

\begin{tabular}{l|c|c|c|c}
\hline Construct & Reward System & Training \& Dev & Job Sat & Emp. Retention \\
\hline Reward System & 0.80 & & & \\
\hline Training \& Dev & 0.54 & 0.71 & & \\
\hline Job Sat & 0.66 & 0.60 & 0.71 & \\
\hline Emp. Retention & 0.64 & 0.55 & 0.71 & 0.76 \\
\hline
\end{tabular}

The tabulated values in Table 3 exceeded the correlations of the latent construct, which is evidence for the discriminant validity. Thus, the conclusion can be drawn that the result achieved discriminant validity for all constructs.

\subsection{Assessment of Structural Model}

In this paper, the author adopted the model developed by Baron and Kenny [93] to test the effect of job satisfaction as a mediating variable on two dependent variables - the reward system and training and development - using a multiple regression test [94]. Regression and correlation analysis were used to determine the importance of the relationship between the variables in this study.

Therefore, the model underwent a set of procedures. Once the CFA analysis had been completed and all values met the required thresholds for validity and reliability, the measurement models for all latent constructs involved in the model were validated. Then, these constructs were assembled into the structural model to execute the SEM. The constructs were 
arranged from left to right, beginning with the exogenous constructs at the far left, followed by the mediator constructs in the middle, and the endogenous construct at the far right. The output that resulted from executing the SEM is provided in Figure 3 for the standardized regression path coefficients and the regression path coefficients between constructs.

The text output for every direct effect relationship in this study, as depicted by Figure 3, is presented in Table 4. The testing of the hypotheses in Table 5 is decided based on the probability value (p-value). The hypothesis is significant if the P-value obtained is less than the type 1 error value (alpha) 0.05 [89, 95]. Based on that, the results of the proposed hypotheses were determined, as shown in Table 5.

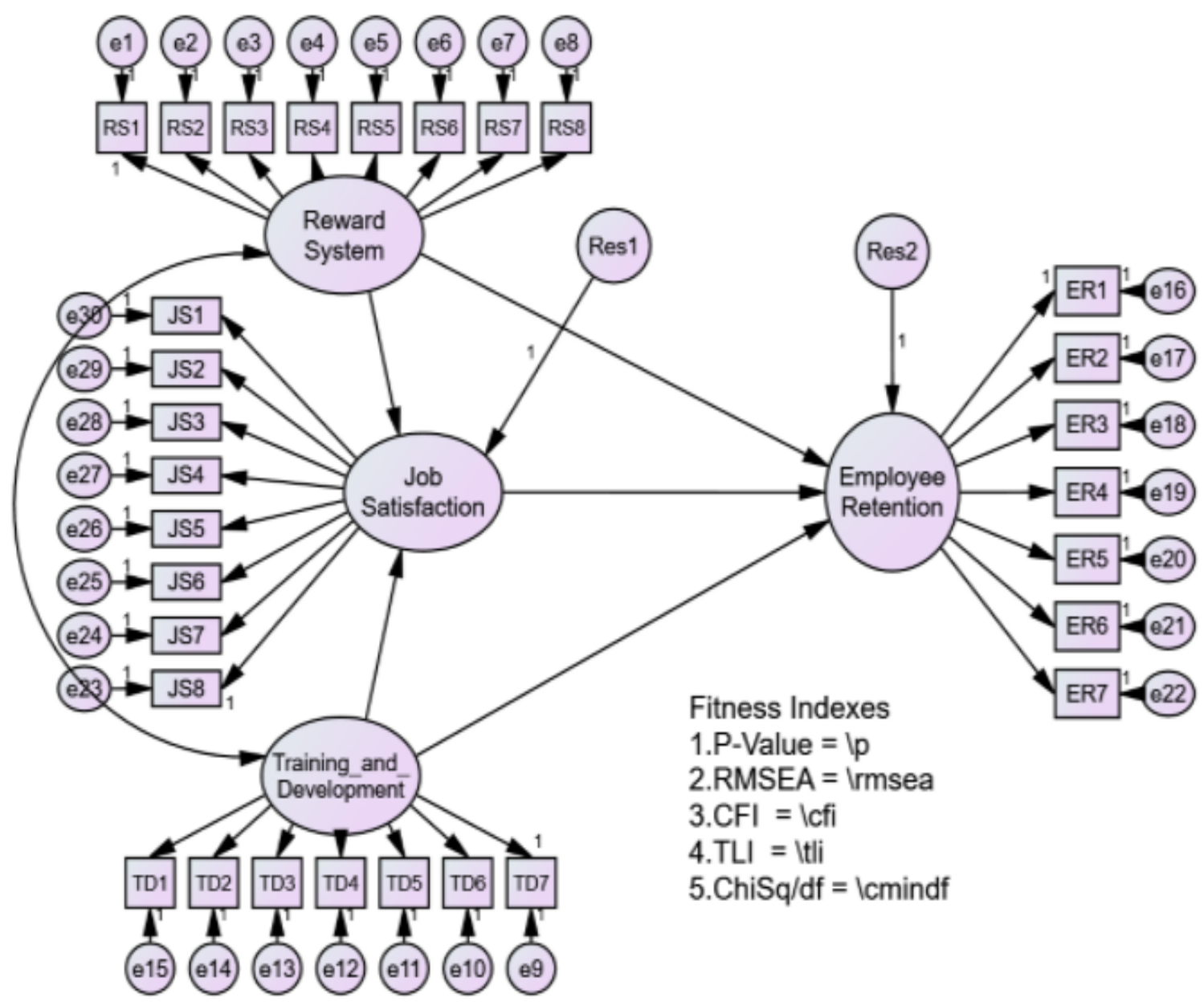

Figure-3.

The Structural Model in IBM SPSS AMOS Graphic.

The explanation regarding the performance of $\mathrm{R}^{2}$ (coefficient of multiple determination) of the model (obtained from Figure 3) is explained in Table 4.

Table-4.

The Regression coefficient (beta).

\begin{tabular}{l|l|l|c|c|c|c|l}
\hline & & & Estimate & S.E. & C.R. & P & Result \\
\hline Job Satisfaction & $<---$ & Reward System & 0.388 & 0.070 & 5.551 & 0.001 & Significant \\
\hline Job Satisfaction & $<---$ & Training and Development & 0.279 & 0.068 & 4.081 & 0.001 & Significant \\
\hline $\begin{array}{l}\text { Employee } \\
\text { Retention }\end{array}$ & $<---$ & Job Satisfaction & 0.527 & 0.115 & 4.570 & 0.001 & Significant \\
\hline $\begin{array}{l}\text { Employee } \\
\text { Retention }\end{array}$ & $<---$ & Reward System & 0.242 & 0.078 & 3.104 & 0.002 & Significant \\
\hline $\begin{array}{l}\text { Employee } \\
\text { Retention }\end{array}$ & $<---$ & Training and Development & 0.131 & 0.073 & 1.787 & 0.074 & Not Significant \\
\hline
\end{tabular}


Table-5.

The hypothesis testing for direct effect.

\begin{tabular}{l|l|c|c}
\hline & Direct Effect Hypothesis & P-Value & Result \\
\hline H1 & $\begin{array}{l}\text { Reward System has a significant effect on Job Satisfaction among employees in } \\
\text { the Yemeni banking sectors. }\end{array}$ & 0.001 & Supported \\
\hline H2 & $\begin{array}{l}\text { Training \& Development has a significant effect on Job Satisfaction among } \\
\text { employees in the Yemeni banking sectors. }\end{array}$ & 0.001 & Supported \\
\hline H3 & $\begin{array}{l}\text { Reward System has a significant effect on Employee Retention in the Yemeni } \\
\text { banking sectors. }\end{array}$ & 0.002 & Supported \\
\hline H4 & $\begin{array}{l}\text { Job Satisfaction has a significant effect on Employee Retention in the Yemeni } \\
\text { banking sectors. }\end{array}$ & 0.001 & Supported \\
\hline H5 & $\begin{array}{l}\text { Training \& Development has a significant effect on Employee Retention in the } \\
\text { Yemeni banking sectors. }\end{array}$ & 0.074 & $\begin{array}{c}\text { Not } \\
\text { Supported }\end{array}$ \\
\hline
\end{tabular}

As outlined by Awang [87]; Awang [88] and Awang., et al. [96] the testing procedure for the mediating variable is presented in Figure 4 and Figure 5.

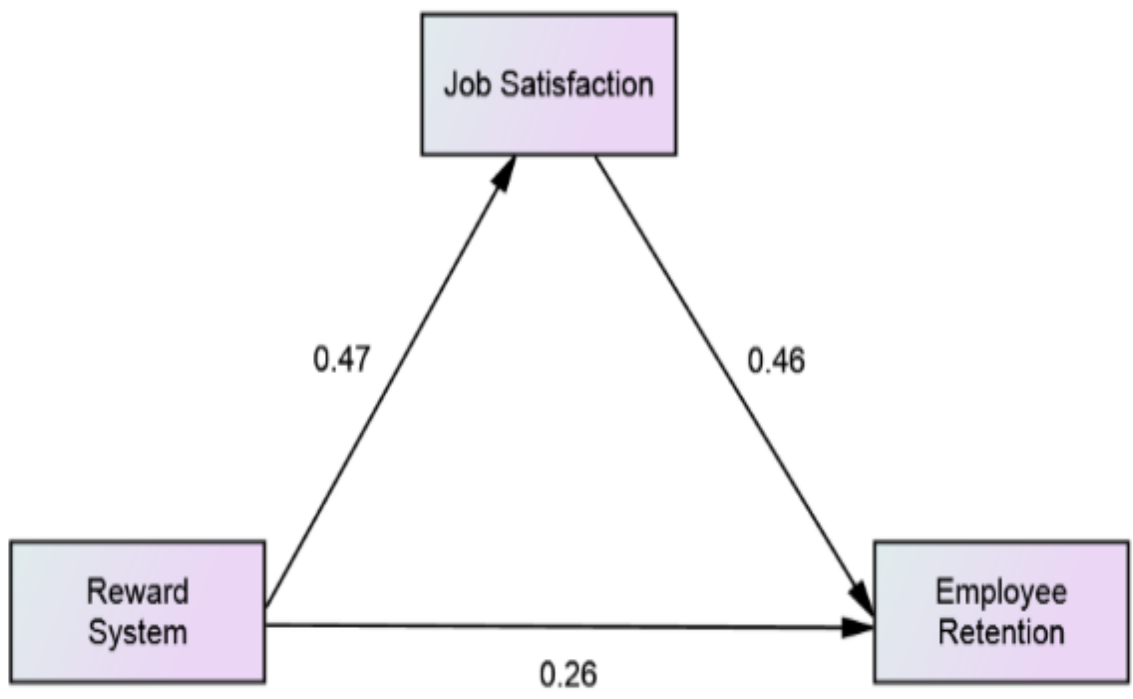

1. The indirect effect1 $\mathbf{a}=0.47$ (Significant)

2. The indirect effect $2 \mathbf{b}=0.46$ (Significant)

3. The direct effect $\mathrm{c}=0.28$ (Significant)

4. Thus, the mediation occurs since both $\mathrm{a}$ and $\mathrm{b}$ are significant

5. The type of mediation is partial mediation since the direct effect $\mathbf{c}$ is also significant.

Figure-4.

Testing the mediator in the path RS to JS to ER. 

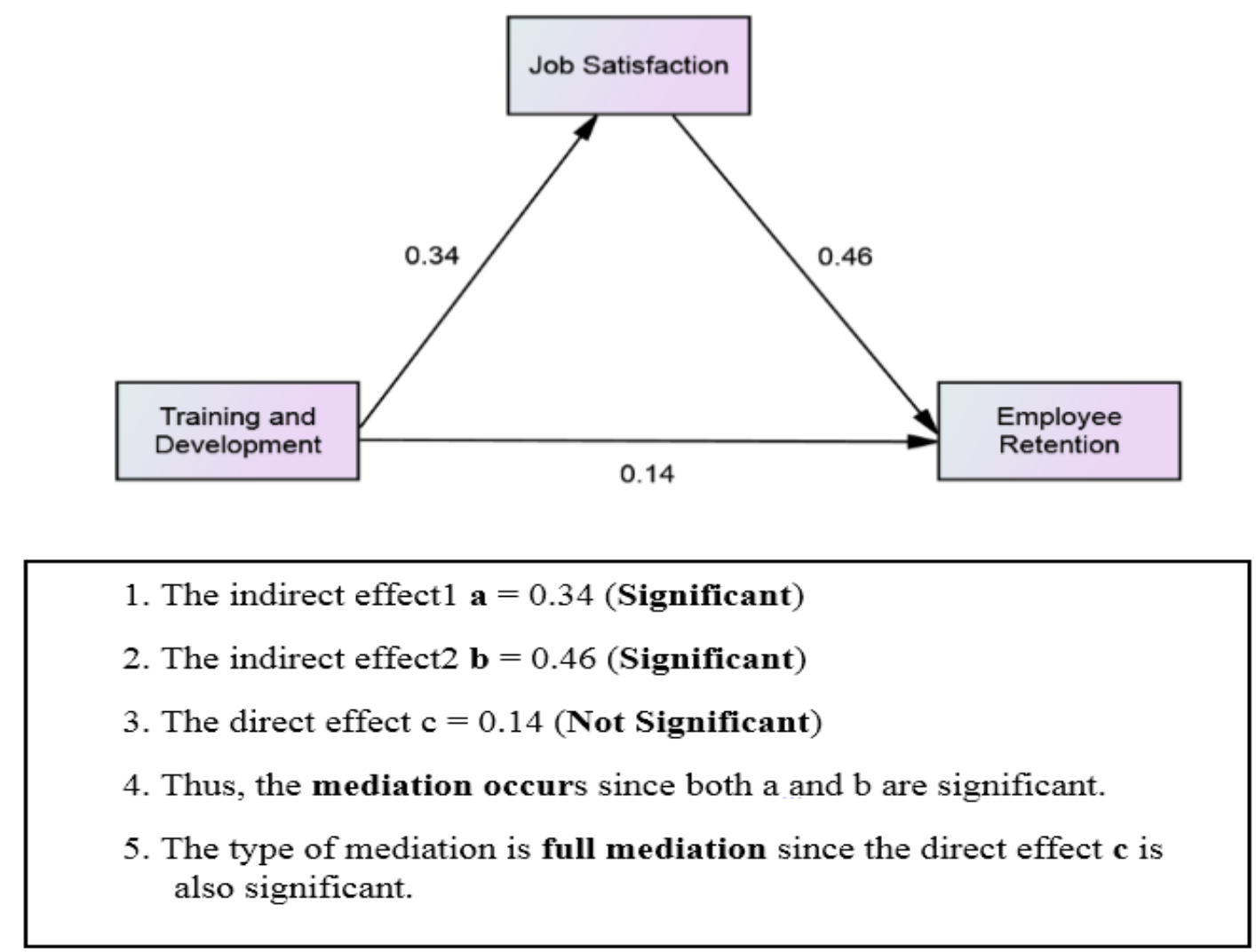

Figure-5.

Testing the mediator in the path TD to JS to ER.

The hypothesis testing for the mediation effects of the mediator construct in the model is carried out separately, as shown in Table 6.

Table-6.

The Hypothesis testing for direct effect.

\begin{tabular}{l|l}
\hline & The Hypothesis for testing Mediators \\
\hline H6 & $\begin{array}{l}\text { Job Satisfaction mediates the relationship between Reward Systems and Employee Retention } \\
\text { among employees in the Yemeni banking sectors. } \\
\text { Result: This hypothesis is supported. The type of mediation is partial mediation. }\end{array}$ \\
\hline H7 & $\begin{array}{l}\text { Job Satisfaction mediates the relationship between Training \& Development and Employee } \\
\text { Retention among employees in the Yemeni banking sectors. } \\
\text { Result: This hypothesis is supported. The type of mediation is partial mediation. }\end{array}$ \\
\hline
\end{tabular}

\section{Discussion}

Based on a comprehensive review of relevant previous studies, the current study investigated the mediating impact of job satisfaction on the relationship between independent variables (reward system and training and development) and employee retention in Yemen's banking sector, using the general quantitative inquiry approach by Cross-sectional designs.

The quantitative result was determined by a questionnaire, which was conducted in Yemen's commercial banks. Additionally, the study used SEM, through AMOS software, to test hypotheses on the variables. The results of the current research study show that reward system and training and development both have a significant effect on job satisfaction. When there is job satisfaction, and employees are satisfied with their work in an organization, their turnover intention will be lower or non-existent.

The organization will retain its employees, and the staff will be committed to that organization. Employee satisfaction can be described as their feelings relating to the organization and their comfort there. Based on the results of this study and empirical evidence, job satisfaction is crucial to employee retention, which is essential for an organization to achieve profitability and competitiveness.

\subsection{Conclusion}

The results demonstrate that six out of seven hypotheses are supported by the experimental results (the reward system and training and development have a positive and statistically significant effect on job satisfaction, and job satisfaction has a positive and statistically significant effect on employee retention, while job satisfaction fully mediated the relationships between the reward system and training and development and employee retention). 
At the same time, the fifth hypothesis, regarding the effect of training and development on employee retention in the banking sector of Yemen, did not display a statistically significant result. Thus, the provision of training and development does not play a critical role in employee retention.

Job satisfaction has been highlighted along with the bonus system as a major tool banks can utilize in the struggle for employee retention. Organizations worldwide must focus more on their human resources because they are the main pillar upon which organizations depend.

\section{References}

[1] A. S. Emam, J. B. Jais, and M. I. Tabash, "Training practices and organizational commitment in the Yemeni Islamic banking sector: The mediating role of Tribalism," Journal of Business and Retail Management Research, vol. 13, pp. 292 -302, 2019.

[2] A. A. Khan, S. Abbasi, R. M. Waseem, M. Ayaz, and M. Ijaz, "Impact of training and development of employees on employee performance through job satisfaction: A study of telecom sector of Pakistan," Business Management and Strategy, vol. 7, pp. 29-46, 2016.Available at: https://doi.org/10.5296/bms.v7i1.9024.

[3] C. R. Proctor, "Effective organizational communication affects employee attitude," Doctoral Dissertation, Southern Utah University, 2014.

[4] M. Rageh, A. Nasser, and F. Al-Muslimi, "Yemen without a functioning central bank: The loss of basic economic stabilization and accelerating famine. Sana'a Center for Strategic Studies, November 2, 2016. Retrieved from: http://sanaacenter.org/publications/mainpublications/55. [ Accessed June 29, 2018]," 2016.

[5] F. A. Shawtari, M. Ariff, and S. H. A. Razak, "Efficiency and bank margins: A comparative analysis of Islamic and conventional banks in Yemen," Journal of Islamic Accounting and Business Research, vol. 10, pp. 50-72, 2019.Available at: https://doi.org/10.1108/JIABR-07-2015-0033.

[6] B. B. Neog and M. Barua, "Factors affecting employee's retention in automobile service workshops of Assam: An empirical study," The SIJ Transactions on Industrial, Finance \& Business Management (IFBM), vol. 3, pp. 9-18, 2015.Available at: https://doi.org/10.9756/sijifbm/v3i6/03010030102.

[7] F. Appiah, E. Kontor, and D. Asamoah, "Effect of human management practices on employee retention: Perspectives from the mining industry in Ghana," International Research Journal of Arts and Social Sciences, vol. 2, pp. 31-48, 2013.

[8] A. E. Khatib, "The post war performance of the Lebanese banks using the balanced scorecard: A case study," International Journal of Management and Sustainability, vol. 9, pp. 54-75, 2020.Available at: https://doi.org/10.18488/journal.11.2020.92.54.75.

[9] K. M. Kyi, Factor affecting employee retention in non-profit organizations. Philippine: Adventist International Institute of Advance Studies, 2011.

[10] M. Mehta, A. Kurbetti, and R. Dhankhar, "Review paper-study on employee retention and commitment," International Journal of Advance Research in Computer Science and Management Studies, vol. 2, pp. 154-164, 2014.

[11] T. V. Sung and V. Savaspakdee, "The deteriorating role of active transactional leadership on employees perceived uncertainty and emotional exhaustion: Evidence from educational sector of Thailand," Journal of Contemporary Research in Business, Economics and Finance, vol. 3, pp. 60-69, 2021.Available at: https://doi.org/10.33094/26410265.2021.33.60.69.

[12] R. E. B. E. C. C. A. Dei-Mensah, "Effects of human resource management practices on retention of employees in the banking industry in Accra, Ghana," Doctoral Dissertation, Kenyatta University, 2014.

[13] C. L. Lam, S. F. Law, Y. J. Loo, W. Y. Ng, and S. L. Ooi, "A study on factors affecting employee retention in nursing industry at Klang Valley," Doctoral Dissertation, UTAR, 2015.

[14] A. Imran, S. Ahmad, Q. A. Nisar, and U. Ahmad, "Exploring relationship among rewards, recognition and employees' job satisfaction: A descriptive study on libraries in Pakistan," Middle-East Journal of Scientific Research, vol. 21, pp. 1533-1540, 2014.Available at: https://doi.org/10.5829/idosi.mejsr.2014.21.09.21720.

[15] Y. Cheng, "Looking back, moving forward: A review and reflection of the organization-public relationship (OPR) research," Public Relations Review, vol. 44, pp. 120-130, 2018.Available at: https://doi.org/10.1016/j.pubrev.2017.10.003.

[16] R. E. Kranton, "Identity economics 2016: Where do social distinctions and norms come from?," American Economic Review, vol. 106, pp. 405-09, 2016.Available at: https://doi.org/10.1257/aer.p20161038.

[17] L. Kalén, "Linking pay to performance-critical issues to consider. Haaga-Helia- universty of Applied Sciences," Master Thesis - Degree programme in international Businees Management 2017, 2017.

[18] E. P. Lazear, "Compensation and Incentives in the Workplace," Journal of Economic Perspectives, vol. 32, pp. 195-214, 2018.Available at: https://doi.org/10.1257/jep.32.3.195.

[19] Z. Fisseha-Zemene, "A Thesis Submitted To St . Mary' S University, School of Graduate Studies in Partial Fulfillment of the Requirements for the Degree of Master of Business. June, 1-66," 2018.

[20] A. Elnaga and A. Imran, "The effect of training on employee performance," International Journal of Recent Technology and Engineering, vol. 7, pp. 6-13, 2018.

[21] R. S. Butt, X. Wen, and R. Y. Hussain, "Mediated effect of employee job satisfaction on employees' happiness at work and analysis of motivational factors: Evidence from telecommunication sector," Asian Business Research Journal, vol. 5, pp. 1927, 2020.Available at: https://doi.org/10.20448/journal.518.2020.5.19.27.

[22] M. Armstrong and S. Taylor, Armstrong's handbook of human resource management practice. United Kingdom: Michael Armstrong, 2014.

[23] J. Hanaysha and P. R. Tahir, "Examining the effects of employee empowerment, teamwork, and employee training on job satisfaction," Procedia - Social and Behavioral Sciences, vol. 219, pp. 272-282, 2016.Available at: https://doi.org/10.1016/j.sbspro.2016.05.016.

[24] H. Alrazehi and N. A. Amirah, "A review of training and development towards employee retention in the banking sector," The Journal of Management Theory and Practice (JMTP), vol. 1, pp. 16-21, 2020.Available at: https://doi.org/10.37231/jmtp.2020.1.2.32.

[25] N. I. Chaudhry, M. A. Jariko, T. Mushtaque, H. A. Mahesar, and Z. Ghani, "Impact of working environment and training \& development on organization performance through mediating role of employee engagement and job satisfaction," European Journal of Training and Development Studies, vol. 4, pp. 33-48, 2017. 
[26] H. A. A. W. Alrazehi, N. A. Amirah, A. S. M. Emam, and A. R. Hashmi, "Proposed model for entrepreneurship, organizational culture and job satisfaction towards organizational performance in international bank of Yemen," International Journal of Management and Human Science (IJMHS), vol. 5, pp. 1-9, 2021.

[27] A. Mehrad, H. Redzuan, and H. Abdullah, "The role of personality factors on job satisfaction among academic staff at public research university," Journal of Educational, Health and Community Psychology, vol. 4, pp. 20-28, 2015.

[28] A. Raziq and R. Maulabakhsh, "Impact of working environment on job satisfaction," Procedia Economics and Finance, vol. 23, pp. 717-725, 2015.Available at: https://doi.org/10.1016/s2212-5671(15)00524-9.

[29] Q. Abbas, M. A. Khan, and J. Hussain, "Relationship between types of rewards and job satisfaction of employees: Evidence from Khyber Pakhtunkhwah," Pakistan Business Review, vol. 18, pp. 829-847, 2017.

[30] O. T. Adigun, "Relationship between personal and work-related factors and job satisfaction of Nigerian teachers in special schools," International Journal of Education and Practice, vol. 8, pp. 599-614, 2020.Available at: https://doi.org/10.18488/journal.61.2020.83.599.614.

[31] T. U. Priya and T. S. Eshwar, "Rewards, motivation and job satisfaction of employees in commercial banks-An investigative analysis," International Journal of Academic Research in Business and Social Sciences, vol. 4, pp. 70-78, 2014.Available at: https://doi.org/10.6007/ijarbss/v4-i4/754.

[32] M. Riketta, R. Van Dick, and D. M. Rousseau, "Employee attachment in the short and long run: Antecedents and consequences of situatedand deep-structure identification," Zeitschrift für Personalpsychologie, vol. 5, pp. 85-93, 2006.Available at: https://doi.org/10.1026/1617-6391.5.3.85.

[33] C. Bayliss, A. Novak, V. Nguyen, B. Moran, T. Caelli, S. Harrison, and L. Tracey, "Optimising aircrew training schedules using tabu search," presented at the In Australian Simulation Congress (SimTecT), 2016.

[34] Q. A. Nisar, F. Riasat, and S. Aslam, "Do intrinsic and extrinsic rewards influence the job satisfaction and job performance? Mediating role of reward system," Journal of Management Info, vol. 3, pp. 6-11, 2016.Available at: https://doi.org/10.31580/jmi.v11i1.56.

[35] M. A. Tietjen and R. M. Myers, "Motivation and job satisfaction," Management Decision, vol. 36, pp. 226-231, 1998.Available at: https://doi.org/10.1108/00251749810211027.

[36] E. J. Porfeli and J. T. Mortimer, "Intrinsic work value-reward dissonance and work satisfaction during young adulthood," Journal of Vocational Behavior, vol. 76, pp. 507-519, 2010.Available at: https://doi.org/10.1016/j.jvb.2010.01.004.

[37] S. Hassan, "Impact of HRM practices on employeeâ $\square \mathrm{TM}_{\mathrm{S}}$ performance," International Journal of Academic Research in Accounting, Finance and Management Sciences, vol. 6, pp. 15-22, 2016.Available at: https://doi.org/10.6007/ijarafms/v6i1/1951.

[38] H. Sharma, "Importance and performance of managerial training in Indian companies-an empirical study," Journal of Management Development, vol. 33, pp. 75-89, 2014.Available at: https://doi.org/10.1108/JMD-11-2013-0144.

[39] W.-R. Huang, "Job training satisfaction, job satisfaction, and job performance," Career Development and Job Satisfaction. IntechOpen, 2019.

[40] K. Jehanzeb and J. Mohanty, "Impact of employee development on job satisfaction and organizational commitment: Personorganization fit as moderator," International Journal of Training and Development, vol. 22, pp. 171-191, 2018.Available at: https://doi.org/10.1111/ijtd.12127.

[41] M. Rahayu, F. Rasid, and H. Tannady, "The effect of career training and development on job satisfaction and its implications for the organizational commitment of regional secretariat (SETDA) Employees of Jambi Provincial Government," International Review of Management and Marketing, vol. 9, pp. 79-89, 2019.

[42] K. K. Paposa and Y. M. Kumar, "Impact of training and development practices on job satisfaction: A study on faculty members of technical education institutes," Management and Labour Studies, vol. 44, pp. 248-262, 2019.Available at: https://doi.org/10.1177/0258042x19851649.

[43] B. Roy, "A study on employee retention factors in the Indian banking industry-An empirical study," International Journal of Advance Research in Computer Science and Management Studies, vol. 3, pp. 346-352, 2015.

[44] T. T. Tran, "Enhancing graduate employability and the need for universityenterprise collaboration," Journal of Teaching and Learning for Graduate Employability, vol. 7, pp. 58-71, 2016.Available at: https://doi.org/10.21153/jtlge2016vol7no1 art598.

[45] A. H. Khan and M. Aleem, "Impact of job satisfaction on employee turnover: An empirical study of Autonomous Medical Institutions of Pakistan," Journal of International Studies, vol. 7, pp. 122-132, 2014.Available at: https://doi.org/10.14254/2071-8330.2014/7-1/11.

[46] A. Belete, "Turnover intention influencing factors of employees: an empirical work review," Journal of Entrepreneurship \& Organization Management, vol. 7, p. 1000253, 2018.Available at: https://doi.org/10.4172/2169-026x.1000253.

[47] T. D. Smith, "The effects of management on commitment in the retail industry," Doctoral Dissertation, Walden University, 2017.

[48] Z. Cao, J. Chen, and Y. Song, "Do total rewards reduce the core employees' turnover intentions?," International Journal of Business and Management, vol. 8, pp. 62-75, 2013.Available at: https://doi.org/10.5539/ijbm.v8n20p62.

[49] M. Bussin, The remuneration handbook for Africa: A practical and informative handbook for managing and recognition in Africa. Randburg: Knowles Publishing, 2012.

[50] F. F. T. Chiang and T. A. Birtch, "The performance implications of financial and non-financial rewards: An Asian Nordic Comparison," Journal of Management Studies, vol. 49, pp. 538-570, 2012.Available at: https://doi.org/10.1111/j.14676486.2011.01018.x.

[51] S. De Gieter and J. Hofmans, "How reward satisfaction affects employees' turnover intentions and performance: An individual differences approach," Human Resource Management Journal, vol. 25, pp. 200-216, 2015.Available at: https://doi.org/10.1111/1748-8583.12072.

[52] C. S. Akhtar, A. Aamir, M. A. Khurshid, M. M. Q. Abro, and J. Hussain, "Total rewards and retention: Case study of higher education institutions in Pakistan," Procedia - Social and Behavioral Sciences, vol. 210, pp. 251-259, 2015.Available at: https://doi.org/10.1016/j.sbspro.2015.11.365.

[53] B. B. Aguenza and A. P. M. Som, "Motivational factors of employee retention and engagement in organizations," International Journal of Advances in Management and Economics, vol. 1, pp. 88-95, 2012. 
[54] N. Oriaku, E. Oriaku, and K. Nwala, "The relationship between small business employee's work performance and workplace spirituality," International Journal of Emerging Trends in Social Sciences, vol. 9, pp. 29-34, 2020.Available at: https://doi.org/https://doi.org/10.20448/2001.91.29.34.

[55] J. A. Ogunjimi, "Corporate social responsibilities and firm performance," Asian Business Research Journal, vol. 5, pp. 55-61, 2020.Available at: https://doi.org/10.20448/journal.518.2020.5.55.61.

[56] P. Gupta, "Firm survival through semi-exits: The case of Indian registered manufacturing," Asian Journal of Economics and Empirical Research, vol. 6, pp. 148-168, 2019.Available at: https://doi.org/10.20448/journal.501.2019.62.148.168.

[57] M. Quratul-Ain, "Impact of employees motivation on organizational effectiveness," Business Management and Strategy, vol. 3, pp. 36-45, 2012.Available at: https://doi.org/10.5296/bms.v3i1.904.

[58] M. Moussa, "A review of human resource information systems (HRISs) in organizations," SIU Journal of Management, vol. 4, pp. 1-34, 2014.

[59] C. Sinha and R. Sinha, "Factors affecting employee retention: A comparative analysis of two organizations from heavy engineering industry," European Journal of Business and Management, vol. 4, pp. 145-163, 2012.

[60] N. Zafar, S. Ishaq, S. Shoukat, and M. Rizwan, "Determinants of employee motivation and its impact on knowledge transfer and job satisfaction," International Journal of Human Resource Studies, vol. 4, pp. 1-20, 2014.Available at: https://doi.org/10.5296/ijhrs.v4i3.5874.

[61] R. Manzoor, N. Ahmad, A. Hussain, and M. Hameed, "Impact of rewards on job satisfaction evidences from Ttelecom sector of Pakistan," Arabian Journal of Business and Management Review (OMAN Chapter), vol. 4, pp. 47-60, 2015.Available at: https://doi.org/10.12816/0019101.

[62] S. S. Herman, "The motivation of quantity surveyors in the Malaysian construction industry for improved job performance," Doctoral dissertation, University of Salford, 2016.

[63] S. R. Terera and H. Ngirande, "The impact of rewards on job satisfaction and employee retention," Mediterranean Journal of Social Sciences, vol. 5, pp. 481-487, 2014.Available at: https://doi.org/10.5901/mjss.2014.v5n1p481.

[64] M. Mackay, "Professional development seen as employment capital," Professional Development in Education, vol. 43, pp. 140-155, 2017.Available at: https://doi.org/10.1080/19415257.2015.1010015.

[65] R. Hosseini, "Role of the entrepreneurship in the development of industry," Journal of Contemporary Research in Business, Economics and Finance, vol. 1, pp. 1-11, 2019.Available at: https://doi.org/10.33094/26410265.2019.11.1.11.

[66] C. Ibeabuchi, A. J. Ehido, and N. A. H. N. Abdullah, "The impact of entrepreneurial orientation on export performance of New Zealand's SMEs: The mediating effect of networking capability," International Journal of Social Sciences Perspectives, vol. 7, pp. 34-45, 2020.Available at: https://doi.org/https://doi.org/10.33094/7.2017.2020.71.34.45.

[67] J. D. DeBode, K. W. Mossholder, and A. G. Walker, "Fulfilling employees' psychological contracts: Organizational socialization's role," Leadership \& Organization Development Journal, vol. 38, pp. 42-55, 2017.Available at: https://doi.org/10.1108/lodj-02-2015-0014.

[68] N. N. Thang and Y. Fassin, "The impact of internal corporate social responsibility on organizational commitment: Evidence from Vietnamese service firms," Journal of Asia-Pacific Business, vol. 18, pp. 100-116, 2017.Available at: https://doi.org/10.1080/10599231.2017.1309617.

[69] L. W. Lee and M. M. B. Abdullah, "Organizational justice and employee deviance among emergency services personnel in Malaysia," Journal of Contemporary Research in Business, Economics and Finance, vol. 1, pp. 62-73, 2019.Available at: https://doi.org/10.33094/26410265.2019.14.62.73.

[70] J. Nelissen, A. Forrier, and M. Verbruggen, "Employee development and voluntary turnover: Testing the employability paradox," Human Resource Management Journal, vol. 27, pp. 152-168, 2017.Available at: https://doi.org/10.1111/17488583.12136.

[71] R. El-Bedawy, O. Ramzy, A. Maher, and O. H. Eldahan, "The role of training, democratization, and self-actualization in addressing employee burnout," International Business Research, vol. 10, pp. 93-105, 2017.Available at: https://doi.org/10.5539/ibr.v10n8p93.

[72] R. Mohamed, T. K. Ngui, and B. Mulili, "Factors determining employee retention in the banking sector: A case study of Agricultural Bank of Sudan," Journal of Education \& Entrepreneurship, vol. 4, pp. 1-23, 2017.

[73] M. Shuttleworth, ""Definition of research". Experiment resources. Retrieved from: http://www.Experiment-Research.com. [Accessed Date: 27/1/2014]," 2008.

[74] M. Mitchell and J. Jolley, Research design explained: Cengage Learning. Belmont: Thomson Wadsworth, 2012.

[75] U. Sekaran and R. Bougie, Research methods for business: A skill building approach, 5th ed. Chichester: John Wiley \& Sons, Ltd, Publication, 2010.

[76] J. Hair, R. Anderson, R. Tatham, and W. Black, Multivariate data analysis. Upper Saddle River, NJ: Prentice-Hall International, 2010.

[77] K. Al-Marri, A. M. M. B. Ahmed, and M. Zairi, "Excellence in service: An empirical study of the UAE banking sector," International Journal of Quality \& Reliability Management, vol. 24, pp. 164-176, 2007.Available at: https://doi.org/10.1108/02656710710722275.

[78] M. Jun, S. Cai, and H. Shin, "TQM practice in maquiladora: Antecedents of employee satisfaction and loyalty," Journal of Operations Management, vol. 24, pp. 791-812, 2006.Available at: https://doi.org/10.1016/j.jom.2005.09.006.

[79] S. Bawan, O. Hampus, and K. Magnus, "Satisfaction and its impact on employee retention. linnaeus university," 2016.

[80] J. M. Stanton, E. F. Sinar, W. K. Balzer, A. L. Julian, P. Thoresen, S. Aziz, G. G. Fisher, and P. C. Smith, "Development of a compact measure of job satisfaction: The abridged Job Descriptive Index," Educational and psychological measurement, vol. 62, pp. 173-191, 2002.Available at: https://doi.org/10.1177/001316440206200112.

[81] N. R. Singh, "Measuring the employees," Satisfaction on Reward System - in Case of Development Bank of Ethiopia, vol. 3, pp. 1340-1350, 2018.Available at: https://doi.org/10.18535/afmj/v3i2.06.

[82] M. M. Karim, M. Choudhury, W. Latif, Bin, and M. M. Choudhury, "The impact of training and development on employees' performance: An analysis of quantitative data," Noble International Journal of Business and Management Research, vol. 03, pp. 25-33, 2019.Available at: https://www.researchgate.net/publication/331147751.

[83] Z. Awang, S. Lim, and N. Zainudin, "Pendekatan Mudah SEM- structural equation modelling," Bandar Baru Bangi, MPWS Rich Resources, 2018. 
[84] M. I. Aziz, A. Afthanorhan, and Z. Awang, "Talent development model for a career in Islamic banking institutions: A SEM approach," Cogent Business \& Management, vol. 3, p. 1186259, 2016.Available at: https://doi.org/10.1080/23311975.2016.1186259.

[85] A. S. Shkeer and Z. Awang, "Exploring the items for measuring the marketing information system construct: An exploratory factor analysis," International Review of Management and Marketing, vol. 9, pp. 87-97, 2019.Available at: https://doi.org/10.32479/irmm.8622.

[86] N. A. Rahlin, Z. Awang, A. Afthanorhan, and N. Aimran, "Antecedents and consequences of employee safety climate in the small manufacturing enterprises: Translation, validation and application of the generic safety climate questionnaire," International Journal of Innovation, Creativity and Change, vol. 7, pp. 307-328, 2019.

[87] Z. Awang, A handbook on SEM for academicians and practitioners: the step by step practical guides for the beginners. Bandar Baru Bangi: MPWS Rich Resources, 2014.

[88] Z. Awang, "SEM made simple: A gentle approach to learning structural equation modelling," Bandar Baru Bangi, MPWS Rich Resources, 2015.

[89] N. Asnawi, B. M. Sukoco, and M. A. Fanani, "The role of service quality within Indonesian customers satisfaction and loyalty and its impact on Islamic banks," Journal of Islamic Marketing, vol. 11, pp. 192-212, 2019.Available at: https://doi.org/10.1108/JIMA-03-2017-0033.

[90] A. Shams, M. M. Hoque, A. Siddiqui, Z. B. Awang, S. M. Awaluddin, and T. Baharu, "Exploratory factor analysis of entrepreneurial orientation in the context of bangladeshi small and medium enterprises (SMEs)," European Journal of Management and Marketing Studies, vol. 3, pp. 81-94, 2018.Available at: https://doi.org/10.5281/zenodo.1292331.

[91] J. F. Hair, M. Sarstedt, L. Hopkins, and V. G. Kuppelwieser, "Partial least squares structural equation modeling (PLS-SEM): An emerging tool in business research," European Business Review, vol. 26, pp. 106-121, 2014.Available at: https://doi.org/10.1108/EBR-10-2013-0128.

[92] A. S. Bahkia, Z. Awang, A. Afthanorhan, P. L. Ghazali, and H. Foziah, "Exploratory factor analysis on occupational stress in context of Malaysian sewerage operations," in AIP Conference Proceedings,, 2019, p. 2138.

[93] R. M. Baron and D. A. Kenny, "The moderator-mediator variable distinction in social psychological research: Conceptual, strategic, and statistical considerations," Journal of Personality and Social Psychology, vol. 51, pp. 1173-1182, 1986.Available at: https://doi.org/10.1037/0022-3514.51.6.1173.

[94] P. A. Frazier, A. P. Tix, and K. E. Barron, "Testing moderator and mediator effects in counseling psychology research," Journal of Counseling Psychology, vol. 51, pp. 115-134, 2004.Available at: https://doi.org/10.1037/0022-0167.51.1.115.

[95] A. S. Bahkia., Z. Awang, N. A. Rahlin, and M. Z. A. Rahim, "The importance of supportive leadership in the sewerage operation industry in malaysia: A case of indah water konsortiumprivate limited (iwk)," Humanities and Social Sciences Reviews, vol. 8, pp. 149-162, 2020.Available at: https://doi.org/10.18510/hssr.2020.8317.

[96] Z. Awang, A. Afthanorhan, M. Mamat, and N. Aimran, "Modeling structural model for higher order construct (HOC) using marketing model," World Applied Sciences Journal, vol. 35, pp. 1434-1444, 2017. 